6 Human rights and the environment - a tale of ambivalence and hope $^{1}$

Anna Grear

\title{
Introduction
}

Deeply significant concerns lie behind contemporary efforts to bring human rights law and environmental law into productive and progressive alignment. The twenty first century witnesses the Earth's living systems under relentless and destructive pressure from the adverse impacts of industrial capitalist and consumer lifestyles. Simultaneously_along with the multitudes of defenceless living species adversely affected by environmental degradation — millions of human beings are increasingly placed at profound environmental risk and forced to suffer brutally uneven impacts of economic globalization, deepening vulnerability and escalating violence. ${ }^{2}$

The convergence — or attempted convergence—-between human rights and environmental obligations faces genuinely complex challenges. First, there is the frequently discussed risk of conflicts between, on the one hand, environmental policies, rules, rights and responsibilities and, on the other hand, the human rights to development, privacy and private property. Second, there is a related perception that the methodological individualism of mainstream human rights discourse impedes the collective action necessary to rescue 'the environment ${ }^{3}$ from human practices that degrade its quality. Third, there are ongoing issues concerning rights. These include questions of whose rights and which rights are to take priority in a conflict of legal 
paradigms. Such complexity extends, quite naturally, to the vexed question of whether the two institutionally separated international legal orders of human rights law and environmental law can be reconciled in a productive and progressive manner. ${ }^{4}$

This chapter will argue that international environmental law and international human rights law_-despite the existence of very real separations and tensions between them — show hopeful signs of progress in their relationship. Notwithstanding such hopeful signs, however, both human rights law and environmental law share underlying subject-object relations inimical to their stated aims. This reality, once acknowledged, might, with sufficient imagination, become the departure point for a reconfigured engagement between them and for their transformation.

This chapter will begin by tracing the historical and institutional emergence of international human rights law and international environmental law before analyzing their shared subject-object relations. The chapter will then suggest how these fields of law might be re-imagined and placed on an alternative mutual foundation. Such a foundation could move them towards a more hopeful relationship with their own stated aims and thus enable them to respond more appropriately to the human and environmental crises of the twenty-first century and beyond.

The origins of human rights in international law 
The story of the genesis and evolution of human rights is thousands of years long. Human rights have antecedents in religious traditions emphasizing norms of human to human ethics; in well established philosophical traditions; in early national codes of antiquity; in early international interventions concerning the protection of religious liberty and the abolition of the slave trade; and in the emergence of international humanitarian law and rules concerning the protection of citizens abroad. ${ }^{5}$

However, despite this long antecedent story, traditional accounts of the history of international human rights law generally locate its emergence in a twentieth century post-Second World War fusion of natural law and positive law together with an unprecedented international 'consensus' 'on substantive norms with high moral voltage'. ${ }^{6}$ It is generally agreed by historians of international human rights law that the 1945 United Nations Charter ${ }^{7}$ brought human rights into the sphere of international law. In the process of doing so, the UN Charter achieved the simultaneous internationalization of human rights and the birth of the 'human individual' as a subject—rather than an object—of international law. ${ }^{8}$ These developments authoritatively established the idea that ensuring respect for human rights should no longer be entrusted solely to the power of the nation state. ${ }^{9}$ The international order of human rights created by the UN Charter was relatively limited in scope, but since then the United Nations has been instrumental in the production of an apparently ceaseless and expanding process of setting international human rights standards through an almost kaleidoscopic proliferation of instruments and treaties.

All international human rights treaties take their symbolic and juridical life from the Universal Declaration of Human Rights (UDHR). ${ }^{10}$ Even in 2016 the UDHR 
is widely understood to be the symbolic fulcrum of the international human rights order. It possesses immense symbolic power and exerts a virtually irresistible degree of normative traction. The position of the UHDR at the apex of the system is amply supported by the fact that no state has ever denounced it since the moment of its adoption in 1948 right up until 2016. Indeed, the UDHR was affirmed by the 1993 Vienna Declaration and Programme of Action ${ }^{11}$ - a reassertion of the UHDR's status entirely consistent with its self-enunciation as a 'common standard of achievement for all peoples and all nations'. ${ }^{12}$ The UDHR also inspired an entire generation of postcolonial states. It provided the rights centred template for a host of new national constitutional documents. It is also credited with being the normative source of over two hundred international human rights instruments. As Donnelly puts it, 'for the purposes of international action, 'human rights' means roughly 'what is in the Universal Declaration of Human Rights'.13

It is well recognized that international human rights law has developed in a series of phases or stages. ${ }^{14}$ The initial vigour of human rights standard setting activities by the United Nations chilled in the light of cold war politics. There was a marked lull in the production of human rights documents that remained unbroken until the adoption in 1965 of the International Convention on the Elimination of all Forms of Racial Discrimination (CERD). ${ }^{15}$ This development primarily reflected the concerns of the newly decolonised nations swelling the ranks of United Nations membership and whose concerns were beginning to influence the preoccupations of the international community. ${ }^{16}$ In 1966 there was a second phase of general or universal standard setting when the rights stated in the UDHR found further enunciation in two international legal documents. These are, in narrow chronological 
order, the International Covenant on Economic, Social and Cultural Rights $(\text { ICESCR })^{17}$ and the International Covenant on Civil and Political Rights (ICCPR). ${ }^{18}$ The dichotomy between these two 'categories' of rights is often traditionally explained as reflecting the cold war ideological fracture. However, for many the dichotomy simultaneously reflects perceived differences between the categories of rights in terms of their relative justiciability, their differing operation as primarily 'negative' or 'positive' rights, and their relative enforceability. ${ }^{19}$

Together the UDHR, the ICESCR and the ICCPR are referred to as the 'International Bill of Rights'. They are supplemented, further expressed or implicitly criticized -depending on one' s viewpoint - by later standard setting exercises. These tend to focus either upon specific rights, for example as does the United Nations Convention against Torture and Other Cruel, Inhuman or Degrading Treatment or Punishment (UNCAT) ${ }^{20}$ or upon the holders of specific rights, for example as does the Convention on the Elimination of all Forms of Discrimination against Women $(\mathrm{CEDAW}) .^{21}$ Finally, the almost 'carnivalistic' ${ }^{22}$ expansion of the number of international United Nations human rights treaties has been accompanied, at different times and rates, by the spread and maturation of a set of regional international human rights regimes. ${ }^{23}$ Regional courts have been pivotal in such developments. Similarly, developments at the national level have deepened the juridical potency of human rights.

Human rights, despite their intensifying overlaps and interconnections, were traditionally - and often still are - viewed as having expanded through three generations: 'first generation' civil and political rights; 'second generation' social, 
economic and cultural rights; and 'third generation' solidarity rights. Environmental rights, which are sometimes linked to the 'greening' of human rights, are often placed in the third generation of such rights. ${ }^{24}$

The origins of environmental protection in international law

Compared to human rights law, environmental law is a rather recent legal innovation. There emerged before the middle of the twentieth century a few important and substantively environmentally responsive legal developments: for example, nineteenth century private law rules relating to pollution damage; nineteenth century statutory provisions about public health; and a few international conservation laws that emerged in the $1900 \mathrm{~s}^{25}$ and later. ${ }^{26}$ However, environmental law did not exist as a recognized or a discrete category of law, either internationally or domestically, until the 1960 s. $^{27}$

There is evidence of environmental awareness and concern expressed in the writings of nineteenth century thinkers such as John Muir, John Burroughs, Henry David Thoreau and George Perkins Marsh, ${ }^{28}$ but it was not really until the 1960s that the complex and inter-systemic nature of ecology, the fragility of earth systems and their vulnerability to human activity were well understood. An important moment in the popularization of an emerging environmental consciousness was the publication of Rachel Carson's iconic Silent Spring. ${ }^{29}$ This book evocatively expressed the growing concern that sparked the rapid proliferation of legal arrangements to protect soil, air and ecosystems such as forests and wetlands. These responses emerged 
initially in the United States of America, Europe, New Zealand and Australia. These largely statutory developments were significantly buttressed by grassroots energies and by the activities of non-governmental organizations. Accordingly, concern for the environment steadily became part of the mainstream political agenda. By the 1980s, environmental law was increasingly an important and widely discussed component of international law. ${ }^{30}$

The obvious intimacy between environmental law and environmentalism lends a certain degree of justification to scholars, such as Tarlock, who claim that environmental law is relatively discontinuous with earlier legal traditions because of its special focus upon environmental stewardship. Tarlock argues that the aim of environmental law is 'to change the system of resource use incentives from those that induce unsustainable development to those that induce environmentally sustainable development [and that] [e]nvironmental law is thus a fundamentally new concept with more discontinuity than continuity with past legal and intellectual traditions.' 31

However, there are also rather different views of past legal and intellectual contributions. Coyle and Morrow, for example, argue that environmental law, in effect, revives stewardship ethics predating the industrial revolution. Further, that it is possible to discern in the English common law tradition a philosophical thread running through certain currents of legal thought concerning tort and property and a relationship between public and private law that can accurately be described, in contemporary terms, as being distinctively environmental. ${ }^{32}$ 
For Tarlock, however, environmentalism, as the wellspring of environmental law's concerns, places itself in an explicitly critical relationship to the philosophical and historical antecedents of western global capitalism and its colonial past. Thus environmental law, which he suggests exhibits a high degree of homogeneity across legal systems, for him signals a fundamental shift in values. ${ }^{33}$

It is clear, it is conceded, that there has been a shift, but the strength of Tarlock's claim is frayed not only by the work of scholars such as Coyle and Morrow but also by an examination of the dominant subject-object assumptions shared by human rights law and environmental law - discussed later in this chapter.

Environmentalism may well place itself in a critical relationship to past commitments, but environmental law, as law, continues to reflect antecedent foundations that themselves reflect the complex and contradictory flows and eddies of legal thought and the philosophical suppositions that inform Eurocentric legal culture. This culture continues to a large extent to underwrite international law. ${ }^{34}$ Indeed, it may well be that it is the framework of international law itself that produces the homogeneity of environmental law observed by Tarlock. The analysis of the foundations of international law undertaken later in this chapter indicate that Tarlock's claim concerning the 'value shift' represented by environmental law is somewhat more problematic than he implies.

Whatever its origins, there can be little room for doubt about the growing contemporary homogeneity of environmental law. Yang and Percival go so far as to identify the emergence of what they call 'global environmental law.' This is a development that signals what they describe as: 
a growing convergence around a few principal approaches to environmental regulation... [and a set of] growing international linkages ... blurring the traditional divisions between private and public law and domestic and international law, promoting integration and harmonization. The result has been the emergence of "global environmental law"-a field of law that is international, national, and transnational in character all at once. ${ }^{35}$

This development reflects a shared sense of the increasingly serious implications of environmental realities such as the climate crisis. Moreover, it reflects the combination of national efforts to improve national environmental law and regulation in the context of the ongoing efforts of nation states to coordinate global action through the integration and harmonization of environmental norms at the international level. $^{36}$

Human rights and environmental protection - simultaneous convergence and tension

1 The normative context

The relationship between human rights and environmental protection has become critically important. There has been, perhaps unsurprisingly given the growing sense of human and environmental crisis underpinning the global realities of the late $20^{\text {th }}$ and early $21^{\text {st }}$ centuries, a notable convergence of energies between human rights law 
and environmental law. The two fields, however, still have a somewhat binary relationship and exhibit tensions that 'cannot be wished away'. ${ }^{37}$ The links between the two fields were first explicitly formalized in the Stockholm Declaration at the culmination of the 1972 Stockholm Conference on the Human Environment. ${ }^{38}$ Principle 1 of the Declaration, in particular, establishes an international normative foundation for the importance of linking human rights and environmental concerns: 'Man has the fundamental right to freedom, equality and adequate conditions of life, in an environment of a quality that permits a life of dignity and well-being'. ${ }^{39}$

According to this formulation, a healthy environment is understood to be a precondition for the fulfillment of human rights. This is an approach, perhaps unsurprisingly, echoed by 'many human rights tribunals and experts [for whom environmental protection is] a precondition to the enjoyment of several internationally guaranteed human rights, especially the rights to life and health'. ${ }^{40}$ The relationship between human rights and the environment in this formulation reflects an axiomatic anthropocentrism often criticized by environmental activists. Additionally, in some respects the relationship between human rights law and the environment moves in two directions: for example, various international environmental agreements conceptualize human rights as key mechanisms for achieving environmental goals ${ }^{41}-$ a position amounting, perhaps, to a certain degree of institutional instrumentalism.

Correspondingly, meanwhile, in international human rights law, substantive and procedural human rights entitlements involving environmental considerations and claims are also increasingly common. This evolution clearly does not yet fundamentally challenge the anthropocentric orientation either of international human 
rights law or of international environmental law. Nevertheless, despite this reality, which many regard as a key weakness of human rights based approaches, the Stockholm Declaration is described by Morrow as a 'crucial institutional recognition of the escalating impact of human activity on the environment and a statement of intent to address it.' ${ }^{42}$ And, also on the positive side, the Stockholm Declaration has at least moved responsibility for achieving its environmental goal beyond the involvement of the state towards a broader conception of human responsibility. It does this in two ways. First, it invokes the responsibility of 'citizens and ... enterprises and institutions at every level, all sharing equitably in common efforts'. Second, it notes that 'individuals in all walks of life as well as organizations in many fields, by their values and the sum of their actions will shape the world environment of the future.' 43

\section{Emerging convergences}

The human rights approach to environmental protection has taken three predominant forms: the greening of existing human rights; the pursuit of procedural guarantees through which concerned citizens can make clear their environmental concerns; and arguments centering upon the provision of substantive rights to environmental quality and this includes a 'global environmental right'. ${ }^{44}$ Procedural guarantees aiming at participatory justice in the solving of environmental dilemmas have proved particularly powerful as mechanisms for the pursuit of environmental democracy. Prominent examples are the participatory rights underlined by principle 10 of the Rio Declaration on Environment and Development ${ }^{45}$ and by the Aarhus Convention. ${ }^{46}$ 
The impressive international evolution of environmental rights as constitutional rights has likewise pointed the way to convergence between human rights and environmental concerns. ${ }^{47}$ This is, moreover, a development decisively influenced by civil society initiatives and the energies of human rights and democratic impulses. ${ }^{48}$ Human rights rhetoric and law have thus been highly influential in the search for environmental protection and accountability. It may be that the prime position given to human rights based justifications and normative strategies in this field reflects, among other things, the relative histories of human rights law and environmental law. Human rights law, after all, significantly predates environmental law. Shelton, for example, points out that the paucity of references to the environment in human rights instruments is 'because most human rights treaties were drafted and adopted before environmental protection became a matter of international concern.' 49 In addition, enforcement mechanisms for international human rights law are more developed than those embedded in international environmental law. Accordingly, 'the availability of individual complaints procedures has given rise to extensive jurisprudence from which the specific obligations of states to protect and preserve the environment are detailed'. ${ }^{50}$

Despite the paucity of references to environmental protection in human rights treaties, the juridical links between human rights and the environment have increasingly emerged over time in a range of normative instruments and two of the regional human rights treaties even contain specific provisions on the 'right to environment'. ${ }^{51}$ The increasingly forceful normative energies driving such convergence are also richly evident in the 'environmental rights revolution' analysed by Boyd and by Geller. ${ }^{52}$ More than ninety national constitutions now have codified environmental rights for 
human beings. Arguments are also increasingly made for a freestanding 'right to environment or a global environmental right' ${ }^{53}$ as a way of addressing the shortcomings of environmental law. There is also a nascent case for arguing that something like a right to environmental quality is emerging as a norm of customary international law. ${ }^{54}$

\section{Continuing tensions}

Despite all this progress, important tensions persist. Even the mutual distrust between environmentalists and human rights activists is still palpable. Both sides uneasily eye the other's priorities, even though, as Gearty reminds us, 'the need to bring the environmental and human rights movements together has been rendered both urgent and vital by the impending climate change catastrophe'. ${ }^{55}$ All things considered, and despite evidence of a growing normative convergence, it would be, on balance, deeply premature to assert the untroubled interdependence of human rights and environmental protection. Indeed, their interdependence is often asserted precisely by ignoring the depth of the tensions between them. These tensions do not vitiate interdependence per se but they do render it uneasy in certain respects and point to very profound challenges. And, as just intimated, some of these tensions ultimately reflect underlying concerns over past, present and future injustices particularly well reflected in activist suspicions.

This ultimate concern is captured rather well by Gearty who reminds us that: 
... just as the human rights protagonist has often given the impression that he or she does not care about the natural world, so too have some environmentalists seemed at times to despise people. There is in such activists a potential casualness about humankind which may be understandable emotionally (it is our reckless species which has brought us to the verge of collapse) but which when worked through into policies and positions will—if left unchallenged - invariably involve the poor and the vulnerable (whose personal responsibility for environmental change is nonexistent) paying a heavy price for the polluting and destructive recklessness of others. ${ }^{56}$

Themes reflected in Gearty's comment bring to mind, again, Tarlock's argument that environmental law, unlike human rights law, fundamentally reflects environmentalism. Tarlock, as noted above, suggests that contestation within environment law has increasingly moved to the sidelines as international environmental law has matured and gained greater normative consistency. However, there is good reason to suggest that despite Tarlock's optimism, environmental law overwhelmingly still facilitates 'business as usual', 57 and that greater consistency in environmental law might be predicated on something rather less progressive than an innocent form of environmentalism. This possibility takes this analysis to a review of ambivalence and contradiction in environmental law: a challenge ultimately shared by human rights law. This challenge, in turn, indicates the depth of the need for radically new foundations for human rights law and environmental law alike. 
Human rights and environmental protection - power imbalances, deep assumptions, ambivalence and contradiction

\section{Central structural challenges}

In his 2013 review of environmental law and governance, Turner argues that 'the very design of the law itself is fundamentally predisposed to environmental degradation and forms part of a dysfunctional global legal architecture which cannot achieve environmental sustainability'. ${ }^{58}$ This is a challenging proposition. Turner's conclusion might come as something of a surprise to many, including, perhaps, some environmentalists. But to anyone well versed in critical accounts of law's ideological structures, including those of international human rights law, Turner's conclusion would be unsurprising, if not entirely predictable.

Turner relates his conclusion to the historical development of 'the global legal architecture' of environmental law as part of international law. This architecture, he points out, was not ad hoc,'but was developed through careful and deliberate design'..$^{59}$ Turner is unequivocal that the existing foundational commitments of international law make international environmental law very unlikely to succeed. These foundations, he argues, make it extremely challenging to hold some of the most egregious offenders against environmental standards to account. In particular, the centrality of the corporate form and its interests are of decisive significance for his argument. In his words, 'even during [their] formative years, certain features were being built into [corporations'] design that would eventually have huge impacts on the environment in the modern era'. ${ }^{60}$ Turner concludes that separate legal personality, 
limited liability, the separation between ownership and control of corporations, and the legal duty placed upon company directors to pursue the company's best interests as a profit-making entity are all key structural reasons that explain why environmental legal responses fail to meet important accountability targets for modes of environmental degradation. ${ }^{61}$

Support for Turner's analysis, amongst other sources, comes from the work of Dangerman and Schellnhuber concerning the unsustainability of what they call the 'contemporary industrial metabolism'. ${ }^{62}$ Dangerman and Schellnhuber argue that the unsustainable fossil-nuclear energy system is, in effect, locked in by structural conditions. Significantly, their extensive assessment of the various factors involved in this lock in identifies 'modern corporate law as a crucial system element that has thus far been largely ignored'. ${ }^{63}$ They point to fundamental design features of the juridical corporate form, which are central to the structural features at the heart of Turner's analysis. These features include the intensification of shareholder control, a development that produces an asymmetry operating as a key block to feedback loops capable of liberating energy structures from fossil fuel dependency paths. It should be noted, moreover, that the structural components of the corporate form are increasingly globalized. Critiques of the modern corporate entity are now as relevant for China and Japan as they are for France and Germany, and continue to be particularly salient for the Anglo-American corporate form now so dominant in the international order. ${ }^{64}$

2 Contemporary structural trajectories 
Turner anticipates the response that there are new forms of 'environmentally-facing corporations'. He counters this by arguing that 'even in a corporation that has certain environmental standards, there is still a bottom line as [the corporation] is a business venture that is designed for the creation of profit and therefore such standards can only go so far'. ${ }^{65}$ Structural factors, moreover, are pivotal. Sinden, for example, points out that it is too easy:

to lose sight of the vast power imbalance that still forms the backdrop for the political debate on climate change. Increasingly, ... stories of corporations going green are being spun into a larger cultural narrative of the corporation as redeemed sinner. Like the Grinch stopping at the top of the mountain to hear the joyful voices of the carolers below, the new green corporation has heard the environmental gospel and its heart has grown five sizes. But it would be a mistake to think that the recent concessions of many in the fossil fuel industry with respect to global warming mean that corporations have suddenly come around to represent the best interests of the general public. Corporations are still structured by law to put the short-term profits of shareholders first. Even as they abandon their oppositionist stance and come to the table acknowledging the existence of climate change and the need for regulation to curb it, they will come to the bargaining table with the primary purpose and duty of protecting short-term share price. ${ }^{66}$

Sinden's point highlights the radical power imbalance and market dominance structurally embedded by contemporary neoliberal globalization and ideology. These factors are associated with deepening human vulnerability ${ }^{67}$ and with the climate crisis. ${ }^{68}$ Business corporations have exerted and continue to exert considerable global 
influence, with the complex complicity of neoliberal states. This influence affects, moreover, not only states themselves but also the specialist legal architectures, including the key international institutions, set up to respond to centrally important law and governance challenges, including climate change. ${ }^{69}$ Indeed, the global dominance exercised by the business corporation is the most widely accepted characteristic of the global age for theorists of globalization — whatever else they disagree upon. ${ }^{70}$ The degree of systemic closure is stifling. Transnational corporations $(\mathrm{TNCs})^{71}$ exert almost unimaginable power. They are supported in their dominance by powerful economic institutions, which are themselves 'both a symptom of and a stimulus for globalization'. ${ }^{72}$ These include the International Monetary Fund (IMF), the World Trade Organization (WTO) and the European Central Bank (ECB).

It is not unreasonable to see such current trajectories as continuances of earlier patterns notable in nineteenth century industrialization ${ }^{73}$ and colonialism. ${ }^{74}$. These, and the foundations of the international legal order itself, were deeply entangled in the search by imperial colonial powers for raw materials to fuel progress 'at home'. Both international human rights law and international environmental law are core components of an international legal order built upon distinctively colonial foundations. ${ }^{75}$ As such, they are implicated in highly problematic and questionable modes of privileging and come freighted with the self-same subject-object assumptions that drove European rationalistic expansionism and underpinned colonial orders of hierarchy: human-human and human-nature hierarchies. ${ }^{76}$ Despite the fact that more recently, in both international human rights law and in international environmental law, changing world perspectives have emerged quite clearly in relation to ecological concerns, the underlying tensions remain relatively intractable. 
These tensions directly relate to a history and a lingering contemporaneity of European epistemic mastery. Eurocentric epistemic bias still dominates, notwithstanding counter-hegemonic narratives and participatory mechanisms. ${ }^{77}$

\section{Going deeper}

The subject-object relations between humans and 'their environment' assumed and enacted by colonialism and industrialization are those that Merchant famously implicates in the phrase 'death of nature. ${ }^{78}$ Her analysis centres upon the Cartesian rendering of 'nature' as dead res extensa - mere inert matter - and upon the Baconian inauguration of a distinctively masculinist mode of scientific dominance. This convergence produced a system of values at the top of which a prurient and masterful 'man' was dominant: the subject constructed as epistemic overlord acting on the world as 'object'. In the process an entire hierarchy of human beings considered to be less than fully rational were folded into an imposed order of masculinist European mastery. The less than fully rational included women, children, the indigenous, and the nomadic. The Eurocentric ordering of humanity was accompanied by the elevation of private property and market rationality as 'givens' of civilizational progress. These essentially hierarchizing dynamics are deeply familiar themes to anyone versed in critical accounts of international human rights law which, in line with these patterns, still produces entirely predictable marginalized subjectivities. ${ }^{79}$

These ideological trajectories and formations have produced a situation in which international human rights law has been widely colonized by formations of global corporate capital. ${ }^{80}$ At the same time, as noted above, the very foundations of 
environmental law work against its commitments from 'within. ${ }^{81}$ It is therefore important to face the eco-destructive and inhumane implications of the historically powerful ideological imperatives that haunt the law as subterranean archetypes expressed in tropes of legal subjectivity and sovereignty. These ideological imperatives are emerging with deepening force in the era of neoliberal globalization and of an industrialization-driven Anthropocene crisis. In short, for all the tensions between them that reflect differing fundamental moral impulses and institutional distinctions, international human rights law and international environmental law share the same set of fundamental subject-object relations and the ideologies that feed off them. Both international human rights law and international environmental law exhibit ambivalence and haunting ambiguities that fracture the very hopes they each purport to offer.

What, then, is to be done? What future foundations might bring a renewal of the hope thus far betrayed? New philosophical foundations need to be considered before reflecting on conduits for their values in the form of epistemic access to the juridical order. In short, what might be the future sites of legal 'hearing', whether formal or informal, in which grassroots energies can bring different future histories to bear?

Future foundations and hope renewed

1 The changing contexts of human rights law and environmental law 
The commitments resting upon Cartesian subject-object relations and so central to the underlying ideological tilt of the international legal order have been thoroughly exposed and critiqued by critical legal scholarship. However, as the twenty first century complexity deepens, it seems especially urgent and potentially hopeful to emphasize that the implications of new scientific insights increasingly render Cartesian subject-object relations impossible to maintain with any degree of intellectual plausibility. Such scientific insights and developments, together with the new materialist philosophy that responds to them, push thinking beyond the broadly anti-Cartesian critique offered by critical scholarship towards an essentially postCartesian account of reality. This development has significant implications for the entire range of assumptions upon which human rights law and environmental law alike are based.

Coole and Frost argue that what is at stake in the scientific and technological developments informing new materialism is 'nothing less than a challenge to some of the most basic assumptions that have underpinned the modern world, including its normative sense of the human and its beliefs about human agency, [and] ... its material practices such as the ways we labor on, exploit and interact with nature'. ${ }^{82}$ Such a challenge problematizes the very foundations of human rights law and environmental law and of their relationship. In particular, the collapse of their supposed foundations necessitates a radical questioning of the entire range of assumptions upon which human rights law and environmental law are based including the human subject at their axis. 
The distinctively twenty first century complexities in relation to which human rights law and environmental law must be situated include climate change, instantaneous algorithm-driven global capital flows, population movements, Genetically Modified Organisms [GMOs], bio-engineering, artificial intelligence, robotic systems and the sheer saturation of contemporary life in biotechnologies, digitalization and virtual technologies. These and other such complexities necessarily 'disturb the conventional sense that agents are exclusively humans who possess cognitive abilities, intentionality and freedom to make autonomous decisions and the corollary presumption that humans have the right or ability to master nature'. ${ }^{83}$

2 Philosophical responses to the challenges of twenty first century complexities

What might emerge from a newly de-centred vision of the world in which matter itself has lively agencies and none of the assumed stability or inertia presumed by traditional subject-object relations? Perhaps the first step is to acknowledge the evaporation of the human agent at 'the centre' and to appreciate that humans are, as Philippopoulos-Mihalopoulos has put it, 'thrown' into 'the middle' of a radically open ontology. ${ }^{84}$ New materialism and the sciences with which it engages conclusively demonstrate that there is simply no centre there for the 'human' to occupy. What is revealed is instead an affectable and open entanglement of multiple bodies at multiple scales - from the global to the microscopic. These bodies are both human and nonhuman and, as Haraway puts it, the world unfolds as a 'spatial and temporal web of interspecies dependencies'. ${ }^{85}$ There is no 'autonomous' - in the Kantian sense subject of human rights. There are no stable subject-object categorizations: 'species of 
all kinds, living and not, are consequent on a subject- and object-shaping dance of encounters'. ${ }^{86}$

Accordingly, it makes more sense, as Barad has argued, to eschew any notion of a stable subject-object division at all. But this does not mean abandoning the meaning-making function of boundary-drawing. There may be, as Barad suggests, no 'natural, pure and innocent separations [but this is not to reach] for the rapid dissolution of boundaries'. ${ }^{87}$ Subject and object emerge through intra-actions in an entangled ontology. Distinctiveness emerges from divergence - otherwise 'diffraction patterns'. ${ }^{88}$ It is still meaningful to speak of the 'human' even as there is recognition of the fractures, frays and contingencies accompanying that term. The hermeneutical suspicion of critical legal scholarship retains its relevance. And critique can embrace a more process-based ontology according to which the world is made up not by the interaction of separate entities but by differential patterns of mattering.

This might seem hopelessly philosophical. Yet science now urges such a view of matter and life. Moreover, the shift is deeply practical. It radically resituates the human of human rights law and of environmental law. Humans are resituated by such accounts as being embedded in intelligent and sensitive or sensing engagements of 'world-making entanglements' and the 'material-semiotic nodes or knots in which diverse bodies and meanings coshape one another'. ${ }^{89}$ The call invoked by the shift is a highly intelligent one. It invites a response to the factity of 'our' ontological coconstitution with multiple collaborators, including microscopic collaborators, in the co-production of 'the world'. What does this mean for law? 
3 Re-imagining law through a new materialist lens

First, the 'human' itself, while remaining a meaningful referent, now stands in its full contingency and productivity. The 'human', instead of being a fixed, autonomous agent or subject radically separated from 'nature' by an ontology of disembodiment, stands revealed as continuously emergent and evolutive. The 'human' is always an 'I'/'we' 'in-the-making' and becomes radically folded into the rest of a living open field of liveliness. This forces human beings to have to renegotiate their sense of the possible.

In this light, human rights law and environmental law alike become sites for the generation of response-ability. In other words, for the responsibilization of ways and modes of co-situated and differentially situated living. ${ }^{90}$ Law can no longer hinge upon or revolve around the entitlements of abstractly dignified, rationalistic and exceptionalist human creatures. Human rights - including human rights law - would, in this light, be better understood as a mode of special political and juridical attentiveness to the patterns of privilege and marginalization endured by human 'critters'. 'Human 'critters' themselves are understood - to evoke Haraway - as being entangled with multiple non-human 'critters' of all kinds. Environmental law likewise becomes a field radically open to a new ontology of the middle. ${ }^{91}$ Environmental law is drawn away from abstractionist tendencies and the production of reified categories, such as 'global water', to respond to the material and radically situated complexities revealed by ecological science in intimate conversation with law. ${ }^{92}$ The central task facing human rights law and environmental law alike becomes that of the legal reimagination of the 'situation of the human in a more than human world'. ${ }^{93}$ 
At a practical level, this will mean that law will require a conscious sense of epistemic humility. This involves appreciating the unsustainability of 'the centre' while embracing the energies of 'the in-the-midst-of' new modes of hearing and engagement. In environmental matters, for example, it will require a rejection of law's linear concept of causation and of law's unhelpful focus on a reductive view of 'harm', and a fresh appreciation of law's need to develop the conceptual resources to enable it to respond to the immense systemic complexities of climate crisis and lively ecological energies. ${ }^{94}$ New, possibly as yet unimagined, constituencies of concern will need to be factored in to legal decision-making. These include the perspectives of indigenous peoples; animal movements; ecological patterns and flows; and other material and semiotic sources of insight. In this way a whole range of additional perspectives beyond the idea of the central human agent of Cartesian and Kantian legal foundations must be welcomed into the heart of law's responsiveness to the materialities of the world.

There are already signs of practical developments moving in this direction. These include commons-based environmental governance strategies; new modes of advocacy and hearing; the increasing attempt to include indigenous and other marginalized perspectives in environmental justice questions; the emergence of biocultural rights discourse; the converging energies of social movement activisms; the extension of legal personhood or status to a river in New Zealand; and the enshrining of rights of nature in, for example, the Ecuadorian constitution. Judicially inspired incrementalism, affected by participation rights, is also starting to show shifts 
in a direction more progressive for the relationship between human rights law and environmental law. However, unless the currently assumed foundations of human rights law and environmental law are replaced, progress will remain impeded. The necessary adjustments might take place in various ways. For example, by the spread of new scholarship; by the wildfire of urgent memes; by imaginative litigation and adjudication strategies; by enlightened legal and political norm formulation; and by the trickle-up effect of ground-level ambiguities arising from multiple situated communities of concern that confront law in its entirety with its own ideological and structural limitations. In the final analysis, though, without a significant shift in the fundamental taken for granted of human rights law and environmental law, howsoever achieved, the progressiveness of both will remain inhibited by shared and outmoded foundations inimical to their aims.

\section{NOTES}

${ }^{1}$ This chapter builds on earlier work, particularly A. Grear 'Framing the Project of International Human Rights law: Reflections on the Dysfunctional 'Family' of the Universal Declaration' in C. Gearty and C. Douzinas (eds.) Cambridge Handbook of Human Rights (2012), (Cambridge, Cambridge University Press), pp.17-35; A. Grear, 'Human Rights and New Horizons? Thoughts Towards a New Juridical Ontology' (2015/6) Science, Technology and Human Values, Special Issue (forthcoming). The author would like to thank Professor Louis J. Kotze and Professor Karen Morrow for their invaluable comments and reflections. Any errors remain the author's alone.

${ }^{2}$ Kirby (2006). 
${ }^{3}$ A revealing term exposing the sense in which 'the environment' is that which surrounds a centre: the human subject. For a fuller discussion, see PhilippopoulosMihalopoulos (2011a) and (2011b).

${ }^{4}$ Some of these tensions are explored in Dias (2008).

${ }^{5}$ Shelton (2007, pp.1-9).

${ }^{6}$ De Sousa Santos (2000, pp. 260), Towards a New Legal Common Sense: Law,

Globalization and Emancipation (London: Butterworths).

${ }^{7}$ Charter of the UN, 1 UNTS XVI, 24 October 1945.

${ }^{8}$ See Buergenthal (1997). 'The Normative and Institutional Evolution of International Human Rights' (1997) 19 (4) Human Rights Quarterly 703-23.

${ }^{9}$ For an argument drawing on the quasi-constitutional character of the UN Charter as the basis of a constitutionalized international order, see Fassbender (2009).

${ }^{10}$ GA Res 217 (111) of 10 December 1948, UN Doc A/810 at 71 (1948).

${ }^{11}$ UN Doc A/CONF.157/23 (1993), 25 June 1993, endorsed by GA Res 48/121 of 14 February 1994, [2].

${ }^{12}$ UDHR, Preamble.

${ }^{13}$ Donnelly (2003, p.22).

${ }^{14}$ Buergenthal (1997).

${ }^{15}$ Opened for signature 7 March 1966, 660 UNTS 195 (entered into force 4 January 1969).

${ }^{16}$ Joseph and McBeth (2010), editorial introduction.

${ }^{17}$ Opened for signature 16 December 1966, 993 UNTS 3 (entered into force 3 January 1976).

${ }^{18}$ Opened for signature 16 December 1966, 999 UNTS 171 (entered into force 23 March 1976). 
19 Turner (2008).

${ }^{20}$ Opened for signature 10 December 1984, 1465 UNTC 85 (entered into force 26 June 1987).

${ }^{21}$ Opened for signature 18 December 1979, 1249 UNTS 13 (entered into force 3 September 1981).

${ }^{22}$ Baxi, (2006, p.46).

${ }^{23}$ The European Convention for the Protection of Human Rights and Fundamental Freedoms, 213 UNTS 222 (entered into force 3 September 1953), as amended by Protocols Nos. 3, 5, 8 and 11 (entered into force on 21 September 1970, 20 December 1971, 1 January 1990 and 1 November 1998, respectively); The American Convention on Human Rights OAS Treaty Series No. 36, 1144 UNTS 123 (entered into force 18 July 1978); African Charter on Human and Peoples' Rights (adopted 27 June 1981, entered into force 21 October 1986) (1982) 21 ILM 58 (African Charter); League of Arab States, Arab Charter on Human Rights, 22 May 2004, reprinted in (2005) 12 International Human Rights Reports 893 (entered into force 15 March 2008).

${ }^{24}$ Handl (1992, p.117).

${ }^{25}$ All primarily designed to protect commercially valuable species: See Brown Weiss (1992-93) at 676. Brown Weiss lists the 1902 Convention for the Protection of Birds Useful to Agriculture, the 1916 Convention for the Protection of Migratory Birds in the United States and Canada and the Treaty for the Preservation and Protection of Fur Seals signed in 1911. She notes that '[o]nly one convention focused on wildlife more generally: the 1900 London Convention for the Protection of Wild Animals, Birds and Fish in Africa' (p. 676).

${ }^{26}$ Brown Weiss lists conservation laws of the 1930 s and 40s. 
27 Tarlock (2009).

${ }^{28}$ Johnson and Powell (2014, p.13).

${ }^{29}$ Carson (1962/3).

${ }^{30}$ Tarlock (2009).

${ }^{31}$ Ibid (p.2).

${ }^{32}$ Coyle and Morrow (2004).

${ }^{33}$ Tarlock (2009, pp.2-4).

${ }^{34}$ Anghie (2005).

${ }^{35}$ Yang and Percival (2009, p.616).

${ }^{36}$ Ibid (p.617).

${ }^{37}$ Anderson (1996, p.3).

${ }^{38}$ Stockholm Declaration of the United Nations Conference on the Human

Environment, 16 June 1972, UN Doc A/CONF48/14/Rev.1 (1973).

${ }^{39}$ A formulation whose gendered anthropocentrism is difficult to ignore.

${ }^{40}$ Shelton $(2011, \mathrm{p} . i x)$.

${ }^{41} \operatorname{Ibid}($ p.x).

${ }^{42}$ Morrow (2015).

${ }^{43}$ Stockholm Declaration (n 34) preamble, para 7.

${ }^{44}$ Turner (2013).

${ }^{45}$ UN Doc. A/CONF.151/26 (vol. I); 31 ILM 874 (1992).

${ }^{46}$ Convention on Access to Information, Public Participation in Decision-Making and Access to Justice in Environmental Matters: 2161 UNTS 447; 38 ILM 517 (1999).

${ }^{47}$ Boyd (2012).

${ }^{48}$ Gellers (2015).

${ }^{49}$ Shelton $(2011$, p.x $)$. 
${ }^{50}$ Ibid.

${ }^{51}$ Art 16 of the African Charter on Human and Peoples' Rights: OAU Doc.

CAB/LEG/67/3 rev. 5; 1520 UNTS 217; 21 ILM 58 (1982); Additional Protocol to the American Convention on Human Rights in the Area of Economic, Social and Cultural Rights (San Salvador, Nov. 17, 1988, OAS T.S. 69.

${ }^{52}$ Boyd (2012); Gellers (2015).

53 Turner (2013).

${ }^{54}$ Boyd (2012, pp.111-3).

${ }^{55}$ Gearty (2010, p.21).

${ }^{56}$ Ibid.

57 Turner (2013).

${ }^{58}$ Turner (2013, p.32), emphasis added.

${ }^{59}$ Ibid.

${ }^{60}$ Ibid (p.38).

${ }^{61}$ Ibid.

${ }^{62}$ Dangerman and Schellnhuber (2012).

${ }^{63} \operatorname{Ibid}$ (p.1).

${ }^{64}$ Turner (2013, pp.42-4).

${ }^{65}$ Ibid (p.42).

${ }^{66}$ Sinden (2007, p.268).

${ }^{67}$ Kirby (2006).

${ }^{68}$ Koch (2012).

${ }^{69}$ De Sousa Santos argues emphatically that TNCs are the 'key agents of the new world economy’: De Sousa Santos (2002, p.167).

${ }^{70}$ See Shamir (2005, p.92). 
${ }^{71}$ Paragraph 20 of the UN Document, 'Norms on the Responsibilities of Transnational Corporations and other Business Enterprises with regard to Human Rights' (2003) UN Doc E/CN/.4/Sub.2/2003/12/Rev.2 defines a TNC as 'an economic entity operating in more thanone country or a cluster of economic entities operating in two or more countries - whatever their legal form, whether in their home country or country of activity, and whether taken individually or collectively'.

${ }^{72}$ McCorquodale and Fairbrother (1999, p.737).

${ }^{73}$ Malm and Hornborg (2014).

${ }^{74}$ McLean (2004).

${ }^{75}$ Anghie (2005).

${ }^{76}$ See Huggan and Tiffin (2007) for intimations of these hierarchical patterns.

${ }^{77}$ Adelman (2015).

${ }^{78}$ Merchant (1990).

${ }^{79}$ Otto, (2005); Otto (2006); Kapur (2006).

${ }^{80}$ Evans and Ayers (2006).

${ }^{81}$ Turner (2013).

${ }^{82}$ Coole and Frost (2010) at Kindle Location 137.

${ }^{83}$ Ibid, Kindle Location 250.

${ }^{84}$ Philippopoulos-Mihalopoulos (2011a); (2011b), '... the sound of a breaking string'.

${ }^{85}$ Haraway, (2008, p.11).

${ }^{86}$ Ibid (p.4).

${ }^{87}$ Barad (2007, p.187).

${ }^{88}$ Ibid, Kindle Location 2810. Emphasis added.

${ }^{89}$ Haraway (2008, p.4). 
${ }^{90}$ See Code (2006) for an extended discussion of situated knowledge and the responsibilization of knowing.

${ }^{91}$ Philippopoulos-Mihalopoulos (2011b).

${ }^{92}$ Pallonitty (2015).

${ }^{93}$ Neimanis (2014, p.14).

${ }^{94}$ For a theoretical foundation for a new environmental law, see PhilippopoulosMihalopoulos (2011b).

\section{REFERENCES}

Adelman, S. (2015), 'Epistemologies of Mastery’ in A. Grear and L. J. Kotze, (eds.) Research Handbook on Human Rights and the Environment (Cheltenham, Edward Elgar), pp.9-27.

Anderson, M.R. (1996), 'Human Rights Approaches to Environmental Protection: An

Overview' in A. Boyle and M. Anderson (eds.) Human Rights Approaches to Environmental Protection (Oxford, Oxford University Press), pp.1-24.

Anghie, A. (2005), Imperialism, Sovereignty and the Making of International Law (Cambridge University Press, Cambridge).

Barad, K. (2007), Meeting the Universe Halfway: Quantum Physics and the Entanglement of Matter and Meaning (Durham NC, Duke University Press: Kindle DX Version, retrieved from Amazon.co.uk).

Baxi, U. (2006), The Future of Human Rights (Oxford, Oxford University Press).

Boyd, D.R. (2012) The Environmental Rights Revolution: A Global Study of Constitutions, Human Rights, and the Environment (Berkeley, University Berkeley Press). 
Brown Weiss, E. (1992-3), 'International Environmental Law: Contemporary Issues and the Emergence of a New World Order', 81 Georgetown Law Journal 675. Buergenthal, T. (1997), 'The Normative and Institutional Evolution of International Human Rights', 19(4) Human Rights Quarterly 703-23.

Carson, R. (1962/3) Silent Spring (London: Hamish Hamilton).

Code, L. (2006), Ecological Thinking: The Politics of Epistemic Location (Oxford, Oxford University Press).

Coole, D. and Frost, S. (2010), New Materialisms: Ontology, Agency and Politics (Durham NC, Duke University Press: Kindle DX Version, retrieved from Amazon.co.uk).

Coyle, C. and Morrow, K. (2004), The Philosophical Foundations of Environmental Law, (Oxford, Hart).

Dangerman, J. and Schellnhuber, H.J. (2012), 'Energy Systems Transformation’ 110/7 Proceedings of the National Academy of Sciences of the United States of America, PNAS Early Edition: www.pnas.org/cgi/doi/10.1073/pnas.1219791110 (last accessed: 6th March 2015).

De Sousa Santos, B. (2002), Towards a New Legal Common Sense: Law, Globalization and Emancipation (London, Butterworths).

Dias, A. (2008), 'Human Rights, Environment and Development with Special Emphasis on Corporate Accountability' Human Development Report 2008 Background Paper, available at www.core.ac.uk/download/pdf/6248783.pdf (accessed 7th April 2015).

Donnelly, J. (2003), Universal Human Rights in Theory and Practice (Ithaca, NY, Cornell University Press). 
Fassbender, B. (2009), The United Nations Charter as the Constitution of the International Community (Leiden and Boston, Brill/Nijhoff).

Evans, T. and A. J. Ayers (2006), 'In the Service of Power: The Global Political Economy of Citizenship and Human Rights' 10 Citizenship Studies 239-308.

Gearty, C. (2010), ‘Do Human Rights Help or Hinder Environmental Protection?’ 1/1 Journal of Human Rights and the Environment 7-22.

Gellers, J. C. (2015), 'Explaining the emergence of global constitutional rights: a quantitative analysis' 6/1 Journal of Human Rights and the Environment 75-97. Handl, G. (1992), 'Human Rights and Protection of the Environment: A Mildly "Revisionist" View' in A. A. Cançado Trindade (ed.), Human Rights, Sustainable Development and the Environment (San Jose de Costa Rica/Brasilia, Instituto Interamericano de Derechos Humanas/Banco Interamericano de Desarolo), pp.117142.

Haraway, D. (2008), When Species Meet (Minnesota: University of Minnesota Press). Huggan, G. and H. Tiffin (2007), 'Green Postcolonialism', (2007) 9(1) Interventions: International Journal of Postcolonial Studies 1-11.

Johnson, L. and F. Powell (2014), Environmental Law (Boston: Cengage).

Joseph, S. and A. McBeth (2010), Research Handbook on International Human Rights Law (Cheltenham, Edward Elgar).

Kapur, R. (2006), 'Human Rights in the 21st Century: Take a Walk on the Dark Side', 28 Sydney Law Review 664-687.

Kirby, P. (2006), Vulnerability and Violence: The Impact of Globalisation (London, Ann Arbor, Pluto Press).

Koch, M. (2012), Capitalism and Climate Change: Theoretical Discussion, Historical Development and Policy Responses (Basingstoke, Palgrave Macmillan). 
Malm, A. and A. Hornborg (2014), 'The Geology of Mankind? A Critique of the Anthropocene Narrative', 1/1 The Anthropocene Review 62-9.

McCorquodale, R. and R. Fairbrother (1999), 'Globalization and Human Rights', 21 Human Rights Quarterly 735-66.

McLean, J. (2004), 'The Transnational Corporation in History: Lessons for Today?', 79 Indiana Law Journal 363-77.

Merchant, C. (1990), The Death of Nature: Women, Ecology and the Scientific Revolution (London, Harper Collins).

Morrow, K. (2015), 'Sustainability, Environmental Citizenship Rights and the Ongoing Challenges of Shaping Supra-National Environmental Governance' in A. Grear and L. J. Kotze Research Handbook on Human Rights and the Environment (Cheltenham, Edward Elgar), pp.200-18.

Neimanis, A. (2014), 'Alongside the right to water, a posthumanist feminist imaginary' 5/1 Journal of Human Rights and the Environment 5-24.

Otto, D. (2005), 'Disconcerting “Masculinities": Reinventing the Gendered Subject(s) of International Human Rights Law', in D. Buss and A. Manji (eds.), International Law: Modern Feminist Approaches (Oxford, Hart Publishing), pp.105-29.

Otto, D. (2006), 'Lost in Translation: Rescripting the Sexed Subjects of International Human Rights Law' in A. Orford (ed.), International Law and its Others (Cambridge, Cambridge University Press).

Pallonitty, T. (2015), 'Taking aims seriously - how legal ecology affects judicial decision-making', 6/1 Journal of Human Rights and the Environment 55-74.

Philippopoulos-Mihalopoulos, A. (2011a), ‘... the sound of a breaking string': critical environmental law and ontological vulnerability', 2/1 Journal of Human Rights and the Environment 5-22. 
Philippopoulos-Mihalopoulos, A. (2011b), 'Towards Critical Environmental Law' in Philippopoulos-Mihalopoulos. A. (ed.) Law and Ecology: New Environmental Foundations (Abingdon, Routledge/Glasshouse), pp.18-38.

Shamir, R. (2005), 'Corporate Social Responsibility: A Case of Hegemony and Counter-Hegemony' in B. De Sousa Santos and C. A. Rodrigues-Garavito (eds), Law and Globalisation from Below: Towards a Cosmopolitan Legality (Cambridge University Press, Cambridge), pp.92-117.

Shelton, D. (2007), 'An Introduction to the History of Human Rights Law', The George Washington University Law School Public Law and Legal Theory Working Paper No 346; Legal Studies Research Paper No.346, 1-30.

Shelton, D.L (2011), Human Rights and the Environment Volume 1 (Cheltenham, Elgar).

Sinden, A. (2007), 'Climate Change and Human Rights', 27 Journal of Land Resources and Environmental Law 255-71.

Tarlock, D. (2009), Environmental Laws and their Enforcement Volume 1: 'History of Environmental Law' in Encyclopedia of Life Support Systems (EOLSS). Turner, B. (2008), 'Human Vulnerabilities: On Individual and Social Rights’, http://web.gs.emory. edu/vulnerability/zpdfs/turnerpub.pdf (date of last access 13 July 2011). Turner, S. (2013), A Global Environmental Right (London, Routledge). Yang, T. and R. V. Percival (2009), 'The Emergence of Global Environmental Law', 36 Ecology Law Quarterly 615-664. 